Федоренко О. I., доктор педагогічних наук, професор, завідувач кафедри педагогіки та психології ХНУ ВС;

Шевцов С. О., кандидат педагогічних наук, заступник директора Харківського Науково-дослідного експертно-криміналістичного иеетру МВС України

\title{
ЗМІСТ ПРОФЕСІЙНОЇ КОМПЕТЕНТНОСТІ ПРАЦІВНИКІВ ЕКСПЕРТНОЇ СЛУЖБИ МВС УКРАЇНИ
}

Стаття присвячена визначенню змісту професійної компетентності прачівників експертної служби МВС Украӥни. У статті розкрито напрями діяльності Експертної служби та виділено види судових експертиз. Визначено поняття «судова експертиза» та умови їі проведення відповідно до вимог законодавства України.

Для визначення змісту професійної компетентності судового експерта розглянуто поняття «компетентність» у вузькому та широкому розумінні даного поняття. Визначено структуру поняття «професійна компетентність судового експерта», яка охоплює мотиваційну, предметно-практичну та сферу саморегулящії особистості. У статті показано зв'язок професійної компетентності та професіоналізму фахівия; розкрито критерії, які свідчать про професіоналізм судового експерта.

Ключові слова: судовий експерт; судова експертиза; компетентність; професійна компетентність судового експерта; професіоналізм.

У контексті реформування правоохоронних органів держави та Міністерства внутрішніх справ України (далі - МВС України) у тому числі, нагальною виступає необхідність підвищення вимог до професійнопсихологічної підготовки працівників різних напрямків діяльності. Стосується це і судових експертів - працівників Експертної служби МВС України.

Різні аспекти проблеми формування професійної компетентності фахівців досліджували М. Васильєва, Т. Лебединець, А. Маркова, Л. Петровська, Л. Пуховська, С. Сисоєва, А. Хуторськой та інші. Професійна компетентність працівників правоохоронних органів України була предметом дослідження багатьох зарубіжних та вітчизняних вчених, таких як: О. Бандурка, В. Бакуменко, В. Білоліпецький, С. Бублик, І. Голосніченко, О. Єлісєєв, Н. Кулик, В. Медведєв, В. Плішкін, С. Сливка, В. Соболєв, В. Тюріна та інших.

Mema cmammi - визначити зміст професійної компетентності судового експерта та розглянути співвідношення понять «професіоналізм» та «професійна компетентність» судового експерта.

Фактично, професійна компетентність інтегрує в собі різнобічні знання, вміння, навички та ставлення, які демонструє працівник відповідно до вимог певної професії. Отже, професія судового експерта вимагає від нього як фахівця, перш за все, сукупності відповідних професійних знань, навичок і вмінь, а також сформованості певних професійно важливих особистісних рис та якостей.

Психологічні та педагогічні аспекти формування професійно важливих рис та якостей особистості працівників правоохоронних органів 
досліджували: професійну зрілість та професійну усталеність (Г. Яворська), професійно-моральну стійкість (Г. Штефанич) та моральні якості працівників OBC (А. Грязнов, А. Токман), емоційну стійкість (З. Шайхлісламов), діагностику стресостійкості працівників силових структур (В. Мозговий), професійну мотивацію працівників органів внутрішніх справ (А. Москаленко, Д. Кобзін).

Слід відзначити, що професійна діяльність будь-якого підрозділу Міністерства внутрішніх справ - це діяльність, спрямована на забезпечення законності, правопорядку, боротьбу із злочинністю, захист інтересів громадян. Також діяльність правоохоронних органів спрямована на доказ вини (або невинності) особи, яка здійснила правопорушення (злочин). 3 цією метою, як правило, здійснюється судова експертиза.

Експертна служба МВС України сьогодні є невід'ємною складовою частиною системи експертного забезпечення досудового слідства i правосуддя в Україні, організаційна побудова якої закріплена законодавчо і представлена територіальними науково-дослідними експертнокриміналістичними центрами (далі - НДЕКЦ).

До компетенції територіальних НДЕКЦ належить: забезпечення високої якості оглядів місць скоєння злочинів, виконання широкого спектру криміналістичних експертиз і досліджень, ведення криміналістичних обліків. Організаційно до кожного НДЕКЦ входять відділи: криміналістичних видів досліджень; досліджень у сфері інформаційних технологій; дослідження матеріалів, речовин і виробів; біологічних та психологічних (психіатричних) досліджень; інженерних та економічних досліджень; вибухотехнічних та пожежотехнічних досліджень.

Судова експертиза - це дослідження експертом на основі спеціальних знань матеріальних об'єктів, явищ і процесів, які містять інформацію про обставини справи, що перебуває у провадженні органів досудового розслідування чи суду [4].

Відповідно до ч. 1 ст. 242 Кримінального процесуального кодексу України експертиза провадиться експертом за зверненням сторони кримінального провадження або за дорученням слідчого судді чи суду, якщо для з'ясування обставин, які мають значення для кримінального провадження, необхідні спеціальні знання [1].

Експертом у кримінальному провадженні $\epsilon$ особа, яка володіє науковими, технічними або іншими спеціальними знаннями, має право відповідно до Закону України «Про судову експертизу» на проведення експертизи і якій доручено провести дослідження об'єктів, явищ і процесів, що містять відомості про обставини вчинення кримінального правопорушення, та дати висновок 3 питань, які виникають під час кримінального провадження і стосуються сфери її знань [4].

Таким чином, здійснення судової експертизи вимагає наявності спеціальних знань, які лежать в основі відповідних спеціальностей та спеціалізацій. Експерт повинен мати спеціальні знання у галузі науки, техніки, мистецтва тощо, які необхідні і достатні для того, щоб дати 
висновок $з$ питань, що виникають під час досудового розслідування i судового розгляду. Спеціальні знання набуваються в процесі навчання i практичної діяльності за певною спеціальністю (фахом). Судовими експертами можуть бути фахівці, які мають відповідну вищу освіту, освітньокваліфікаційний рівень не нижче спеціаліста, пройшли відповідну підготовку в спеціалізованих установах Міністерства юстиції України та отримали кваліфікацію судового експерта з певної спеціальності (ст. 10 Закону України «Про судову експертизу») [4].

Здійснення судової експертизи передбачає наявність професійних вмінь у відповідній галузі. Професійні вміння - це засвоєний комплекс професійних операцій та дій, які здійснює фахівець при проведенні експертизи. Основу професійних вмінь становить поєднання спеціальних (професійних) знань і певний досвід їх застосування в різних ситуаціях.

Професійна діяльність судового експерта висуває до нього безліч різних вимог, серед яких найважливіша - наявність розвинених професійно важливих якостей особистості. Відсутність або недостатній розвиток цих якостей можуть перешкоджати нормальному здійсненню експертом його функціональних обов'язків, породжують помилки в його діяльності, викликають процеси професійної дезадаптації і професійної деформації особистості [6].

Для розуміння того, що ми вважаємо під терміном професійна компетентність судового експерта, необхідно з'ясувати підгрунтя та складові цього поняття.

Компетенція (лат. competentia - відповідність, узгодженість): 1) добра обізнаність із чим-небудь; 2) коло повноважень якої-небудь організації, установи або особи. Компетентний (лат. competens - відповідний, спроможний): 1) який має достатні знання в певній галузі; 2) який має певні повноваження [7].

Компетенція включає сукупність взаємопов'язаних якостей особистості (знань, умінь, навичок і способів діяльності), які задаються стосовно певного кола предметів і процесів, та необхідних для якісної продуктивної діяльності стосовно неї.

У процесі аналізу наукової літератури встановлено існування як широкого,так і більш вузького тлумачення поняття «компетентність».

У широкому розумінні компетентність в основному визначається як ступінь зрілості людини, яка припускає певний рівень психічного розвитку особистості (навченість i вихованість) та дозволяє індивіду успішно функціонувати в суспільстві.

У вузькому сенсі компетентність розглядається як діяльнісна характеристика, тобто ступінь включеності людини в діяльність, що передбачає ціннісне ставлення до останньої.

У рамках компетентнісного підходу виділяють два базових поняття: компетенція і компетентність, при цьому перше 3 них «включає сукупність взаємопов'язаних якостей особистості, що проявляються стосовно певного кола предметів і процесів», а друге - співвідноситься із «здатністю, 
оволодінням людиною відповідною компетенцією, що включає іï особистісне ставлення до неї і предмету діяльності».

Сама компетентність розглядається як «здатність до вирішення завдань і готовність до своєї професійної ролі в тій чи іншій сфері діяльності» [7].

Компетентна у певній галузі людина володіє певними знаннями та здібностями, які дозволяють їй обгрунтовано судити про цю галузь й ефективно діяти в ній. До структури загальної професійної компетентності судового експерта, на наш погляд, повинні входити такі основні компоненти [6]:

1) мотиваційна сфера (професійні мотиви, потреби, спрямованість) особистісно-мотиваційна компетентність; загальнокультурна; соціальна.

2) предметно-практична сфера (спеціальні професійні знання, уміння, навички) - практично-діяльнісна, спеціально-наукова; інформаційна; управлінська; комунікативна компетентності.

3) сфера саморегуляції (самооцінка, професійна самосвідомість, ставлення до професійного обов'язку) - психологічна компетентність.

Розглянемо детальніше сферу саморегуляції. Вважається, що до сфери саморегуляції відносять самооцінку, самосвідомість та ставлення особистості до себе, ii усвідомлення себе як особи (індивіда), що здатна на основі порівняння себе з іншими людьми оцінити саму себе, свої знання, поведінку та ін.

У Тлумачному словнику української мови зазначається, що самосвідомість - це ясне розуміння своєї сутності, своїх характерних властивостей, ролі в житті й суспільстві [3, с. 426]. Самосвідомість особистості формується поступово. У своєму розвиткові вона проходить декілька етапів, які пов'язані з усвідомленням віку і діяльності суб'єкта носія самосвідомості. Кожний етап передбачає пізнання себе і оцінення своїх силі можливостей, критичне ставлення до себе і результатів своєї діяльності.

Професійна самосвідомість $є$ особливим феноменом людської психіки, що зумовлює саморегулювання особистістю своїх дій у професійній сфері на основі пізнання професійних вимог, своїх професійних можливостей i емоційно-ціннісного ставлення до себе як до суб’єкта конкретної професійної діяльності.

Отже, вищезазначене дає підстави для ствердження, що професійна самосвідомість - це усвідомлення особистістю самої себе у професійній діяльності, а саме:

-усвідомлення своїх потреб, інтересів, прагнень, ціннісних орієнтацій,

-соціальних ролей і мотивів професійної діяльності;

-оцінка своїх професійних можливостей (знань, умінь, навичок i якостей);

-співвіднесення їх 3 нормативами - суспільно-значущими вимогами професії;

-формування своєї лінії поведінки, власного індивідуального стилю діяльності на основі самооцінки себе як професіонала. 
Під комплексом знань i умінь, що передбачають розвинену самосвідомість судового експерта, слід розуміти такі: а) знання загальних характеристик особистості (спрямованість, характер, темперамент, здібності тощо); б) знання особливостей перебігу психологічних процесів (мислення, пам'ять, уява та ін.); в) знання методів психологічного дослідження для вивчення особистості співрозмовника і діагностики його розвитку; г) вміння 3 переносу психологічних знань у реальну професійну діяльність; д) володіння способами і прийомами психічної саморегуляції.

Таким чином професійну самосвідомість можна розглядати як механізм, який забезпечує саморегулювання особистістю своєї професійної діяльності на основі усвідомлення своїх прагнень і можливостей у даній діяльності. Крім того, професійна самосвідомість є показником ступеня оволодіння експертом даною професією; дозволяє визначити причини своїх успіхів i невдач, вносити необхідні корективи в діяльність, визначати перспективи свого професійного самовдосконалення.

Важливим компонентом самосвідомості особистості $є$ самооцінка, сутність якої полягає в усвідомленні себе і певного ставлення до себе, а тому об'єктивна самооцінка, яка безпосередньо впливає на самовиховання, $є$ основним показником сформованості самосвідомості.

Отже, якщо в судового експерта сформовано комплекс зазначених знань i умінь, то можна говорити про сформованість його психологічної компетентності. Результатом іiі сформованості $є$ розвиток індивідуального стилю діяльності фахівця експертної справи, його творчого потенціалу та культури.

Поняття професійної компетентності тісно пов'язане 3 професіоналізмом. Але перш, ніж розглядати поняття професійна компетентність розглянемо поняття професіоналізм, яке за змістом $\epsilon$ ширшим.

Професіоналізм, який визначається як «оволодіння основами та глибинами якої-небудь професії» містить такі компоненти, як: професіоналізм знань; професіоналізм спілкування; професіоналізм самовдосконалення [3, с. 195].

Професіоналізм знань $є$ підгрунтям формування професіоналізму в цілому, основою цілісної системи «професіоналізм експертної діяльності». Його своєрідність полягає в тому, що знання експертом лише в галузі проведення експертиз не є його основною перевагою.

Професіоналізм знань характеризується високим рівнем компетентності в галузі теоретичних, методологічних, методичних і технологічних знань.

У структурі професіоналізму експертної діяльності особливу роль відіграє професіоналізм спілкування, що передбачає взаємодію суб'єктів професійної (в даному випадку експертної) діяльності з метою пізнання та обміну інформацією за допомогою різних засобів комунікацій у ході сумісної роботи.

Виходячи із зазначених вище складових професіоналізму, ми можемо вважати професіоналом такого працівника експертної служби, який 
відповідає певним критеріям. До критеріїв визначення професіоналізму працівника Експертної служби МВС України слід віднести [6]: 1) особисто тяжіє до професії, мотивований до праці в ній, задоволений нею; 2) освоює норми, еталони професії, досягає в ній майстерності; 3) використовує способи й технології, які необхідні для ефективної професійної діяльності; 4) досягає бажаних сьогодні суспільством результатів у своїй професійній діяльності;5) разом із тим прагне індивідуалізувати свою працю, а також усвідомлено розвиває свою індивідуальність засобами професії; 6) досягає уже сьогодні необхідного рівня професійних якостей, знань і умінь; 7) має і усвідомлює перспективу, зону свого найближчого професійного розвитку, робить все можливе для ऑiі реалізації; 8) відкритий для постійного професійного навчання, накопичення досвіду, в той же час збагачує досвід професії за рахунок особистого творчого внеску; 9) соціально активний в суспільстві, піднімає питання про потреби і досягнення професії в ході суспільних обговорень, разом із тим шукає резерви вирішення проблем у середині професії, не боїться потрапляти в умови конкуренції послуг, що надаються; 10) відданий професії, прагне підтримувати іiі честь і гідність навіть у складних умовах; 11) налаштований до якісної та кількісної еволюції оцінки своєї професійної діяльності, вміє сам це робити, готовий до диференційованої оцінки своєї праці в балах, категоріях, позитивно ставиться до участі у професійних змаганнях.

Наведений перелік критеріїв професіоналізму наближає до опису узагальненої еталонної моделі сучасного експерта-професіонала.

Професіоналізм в Експертній службі МВС України - це, насамперед, здатність судового експерта 3 урахуванням умов і реальних можливостей знаходити найбільш ефективні шляхи та способи реалізації поставлених перед ним службових завдань у межах нормативно визначених повноважень.

Особистість професіонала - це сукупність якостей, властивостей, станів судового експерта, що створюють можливості здійснення ним професійної діяльності і водночас самі змінюються й удосконалюються в ході роботи. Таким чином, критеріями професіоналізму судового експерта є: сформованість професійної мотивації; професійна самосвідомість; професійна культура (культура професійного та міжособистісного спілкування); професійна етика; сформованість системи професійних знань, умінь, навичок; професійні здібності; сформованість професійно-важливих рис та якостей особистості.

Складовою частиною професіоналізму є професійна компетентність, яку визначають як систему знань та вмінь, що постійно розширюються й дозволяють працівникам виконувати професійні завдання 3 високою продуктивністю.

Висновок. Таким чином, професійну компетентність судового експерта розглядаємо як якісну характеристику оволодіння фахівцем своєю професійною діяльністю, яка передбачає: усвідомлення своїх спонукань до цієї діяльності (професійних потреб, інтересів, прагнень, ціннісних орієнтацій, мотивів діяльності, усвідомлення своєї соціальної ролі); 
володіння комплексом професійних знань, вмінь та наявність особистісних якостей як спеціаліста, здатного ефективно виконувати професійні обов’язки. Розглядаючи співвідношення професійної компетентності i професіоналізму судового експерта, вважаємо, що професійна компетентність складає змістову основу його професіоналізму, $\epsilon$ обов'язковим підгрунтям для його формування і розвитку.

Перспективним напрямком подальших досліджень є удосконалення підготовки майбутніх судових експертів до професійної діяльності.

\section{Література}

1. Бандурка О.М. Кримінальний процесуальний кодекс України: науковопрактичний коментар / О. М. Бандурка, С.М. Блажівський, Є.П. Бурдоль та ін.; за заг. ред. Я.В.Тація, В.П. Пшонки, А.В. Портнова. - У 2 т. - Т. 1, 2 - Х.: Право, 2012. - 768 с.; 750 с.

2. Бродовська В. Й., Грушевський В. О., Патрик І. П. Тлумачний російськоукраїнський словник психологічних термінів: словник. - К.: ВД «Професіонал», 2007. $512 \mathrm{c}$.

3. Великий тлумачний словник сучасної української мови / Уклад. і голов. ред. В. Т. Бусел. - К.; Ірпінь: ВТФ «Перун», 2002. - 1440 с.
4. Закон
України
«Про
судову
експертизу» http://zakon.rada.gov.ua/go/laws/show/4038-12/ed19940225 (назва з екрану)

5. Шевцов С.О. Судовий експерт: психологічні аспекти практичної діяльності: метод. посіб. / М-во внутр. справ України; Держ. наук.-дослід. експерт.-криміналіст. Центр М-ва внутр. справ України; [авт.-упоряд.: С.О. Шевцов, С.М. Лозова]. - К.: 2011. $332 \mathrm{c}$.

6. Шевцов С. О. Організація професійно-педагогічної підготовки працівників Експертної служби МВС України (спеціальність 13.00.04 - теорія і методика професійної освіти): дис. канд. пед. наук; Харк. нац. пед. ун-т ім. Г.С. Сковороди. - Харків, 2009. - 217 с.

7. Хуторской А.В. Ключевые компетенции и образовательные стандарты [Текст] // Интернет-журнал «Эйдос». - 2002. - 23 апреля. http://www.eidos.ru/joumal/2002/0423.html
Федоренко Е. И., доктор педагогических наук, профессор, заведуюшая кафедры педагогики и психологии ХНУ ВС Шевцов С. А., кандидат педагогических наук, заместитель директора Харьковского научно-исследовательского экспертно-криминалистического центра МВД Украинь

Статья посвящена определению содержания профессиональной компетентности сотрудников экспертной службы МВД Украины. В статье выделены направления деятельности Экспертной службы МВД Украины. Дано определение понятия «судебная экспертиза» и условия ее проведения в соответствии с требованиями законодательства Украиньл.

Для определения содержания профессиональной компетентности судебного эксперта рассмотрено понятие «компетентность» в узком и широком толковании данного понятия. Определена структура понятия «профессиональная компетентность судебного эксперта», которая охватывает мотивационную, предметно-практическую и сферу саморегулячии личности. B статье показана связь профессиональной компетентности и профессионализма; раскрыты критерии, которые свидетельствуют о профессионализме судебного эксперта.

Ключевые слова: судебный эксперт; судебная экспертиза; компетентность; профессиональная компетентность судебного эксперта; профессионализм. 
Fedorenko Olena, Doctor of Education, Professor, Sergey Shevtsov, Ph.D.

\section{THE PROFESSIONAL COMPETENCE CONTENT OF EMPLOYEES OF THE EXPERT SERVICE OF THE MINISTRY OF INTERIOR OF UKRAINE}

The article is devoted to defining the professional competence content of employees of the expert service of the Ministry of Interior of Ukraine. The article studies the problem research state of professional competence forming of judicial forensics specialists.

The article reveals directions of the expert service activity and distinguishes types of judicial examinations: criminalistics; IT researches; research of materials, substances and products; biological and psychological (psychiatric) researches; explosion and fire researches.

The article defines the term "forensics" and determines the conditions of forensic examination conducting in accordance with the Ukrainian laws. The authors reveal the requirements for forensic examination specialists that gives them rights to carry out research (special knowledge in the relevant field and an appropriate level of educational training).

The article examines the concept of "competence" in a narrow and broad notion to determine the content of the professional competence of a forensic expert. It determines the structure of the term "professional competence of a forensic expert," which includes motivational sphere, subject sphere and sphere of self-identity. Motivational sphere is related to professional motives and needs of a forensic expert as a specialist. Subject sphere reflects the availability of special professional knowledge, abilities, skills and experience. The sphere of self-identity reflects the professional expert's attitude of to the profession and to himself as a specialist that is associated with self-esteem, professional identity, attitude to professional duty.

The article deals with the relationship of professional competence and professionalism; discloses criteria that indicate professionalism of the expert service employees. It is proved that professional competence is semantic basis for professionalism and is mandatory basis for its formation and development.

Key words: forensic expert; forensic examination; competence; professional competence of a forensic expert; professionalism. 